San Jose State University

SJSU ScholarWorks

Mineta Transportation Institute Publications

3-2021

\title{
Evaluating Innovative Financing Mechanisms for the California High-Speed Rail Project
}

\author{
Shailesh Chandra \\ California State University, Long Beach \\ Timothy Thai \\ California State University, Long Beach \\ Vivek Mishra \\ California State University, Long Beach \\ Princeton Wong \\ California State University, Long Beach
}

Follow this and additional works at: https://scholarworks.sjsu.edu/mti_publications

Part of the Transportation Commons

\section{Recommended Citation}

Shailesh Chandra, Timothy Thai, Vivek Mishra, and Princeton Wong. "Evaluating Innovative Financing Mechanisms for the California High-Speed Rail Project" Mineta Transportation Institute Publications (2021). https://doi.org/10.31979/mti.2021.2047

This Report is brought to you for free and open access by SJSU ScholarWorks. It has been accepted for inclusion in Mineta Transportation Institute Publications by an authorized administrator of SJSU ScholarWorks. For more information, please contact scholarworks@sjsu.edu. 


\section{SJSU SAN SOSES STAT}

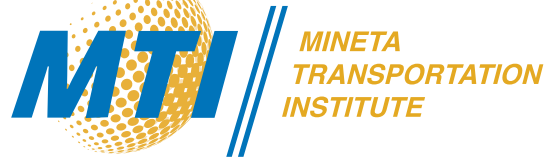

Evaluating Innovative Financing Mechanisms for the California High-Speed Rail Project

Shailesh Chandra, $\mathrm{PhD}$

Timothy Thai

Vivek Mishra

Princeton Wong

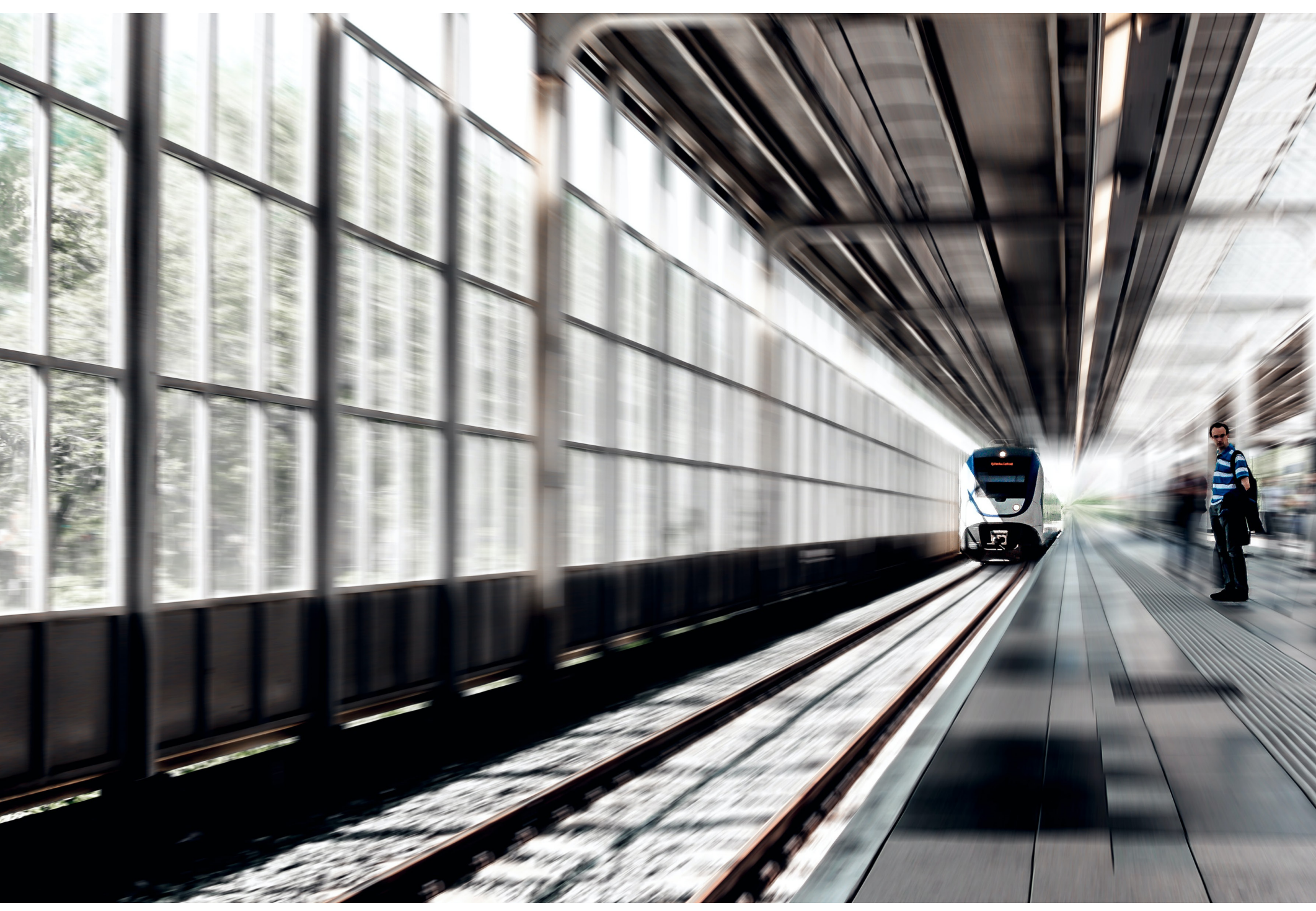

CSUTC California State University

CALIFORNIA STATE UNIVERSITY LONG BEACH 


\section{MINETA TRANSPORTATION INSTITUTE}

Founded in 1991, the Mineta Transportation Institute (MTI), an organized research and training unit in partnership with the Lucas College and Graduate School of Business at San José State University (SJSU), increases mobility for all by improving the safety, efficiency, accessibility, and convenience of our nation's transportation system. Through research, education, workforce development, and technology transfer, we help create a connected world. MTI leads the Mineta Consortium for Transportation Mobility (MCTM) funded by the U.S. Department of Transportation and the California State University Transportation Consortium (CSUTC) funded by the State of California through Senate Bill I. MTI focuses on three primary responsibilities:

\section{Research}

MTI conducts multi-disciplinary research focused on surface transportation that contributes to effective decision making. Research areas include:active transportation; planning and policy; security and counterterrorism; sustainable transportation and land use; transit and passenger rail; transportation engineering; transportation finance; transportation technology; and workforce and labor. MTI research publications undergo expert peer review to ensure the quality of the research.

\section{Education and Workforce Development}

To ensure the efficient movement of people and products, we must prepare a new cohort of transportation professionals who are ready to lead a more diverse, inclusive, and equitable transportation industry. To help achieve this, MTI sponsors a suite of workforce development and education opportunities. The Institute supports educational programs offered by the Lucas Graduate School of Business: a Master of Science in Transportation Management, plus graduate certificates that include High-Speed and Intercity Rail Management and Transportation Security Management. These flexible programs offer live online classes so that working transportation professionals can pursue an advanced degree regardless of their location.

\section{Information and Technology Transfer}

MTI utilizes a diverse array of dissemination methods and media to ensure research results reach those responsible for managing change. These methods include publication, seminars, workshops, websites, social media, webinars, and other technology transfer mechanisms. Additionally, MTI promotes the availability of completed research to professional organizations and works to integrate the research findings into the graduate education program. MTI's extensive collection of transportation-related publications is integrated into San José State University's world-class Martin Luther King, Jr. Library.

\section{Disclaimer}

The contents of this report reflect the views of the authors, who are responsible for the facts and accuracy of the information presented herein. This document is disseminated in the interest of information exchange. MTl's research is funded, partially or entirely, by grants from the U.S. Department of Transportation, the U.S. Department of Homeland Security, the California Department of Transportation, and the California State University Office of the Chancellor, whom assume no liability for the contents or use thereof. This report does not constitute a standard specification, design standard, or regulation. 
Report 21-06

\title{
Evaluating Innovative Financing Mechanisms for the California High-Speed Rail Project
}

\author{
Shailesh Chandra, $\mathrm{PhD}$ \\ Timothy Thai \\ Vivek Mishra \\ Princeton Wong
}

February 2021

\author{
A publication of the \\ Mineta Transportation Institute \\ Created by Congress in 1991 \\ College of Business \\ San José State University \\ San José, CA 95192-0219
}




\section{TECHNICAL REPORT DOCUMENTATION PAGE}

\begin{tabular}{|c|c|c|c|}
\hline $\begin{array}{l}\text { 1. Report No. } \\
21-06\end{array}$ & 2. Government Accession No. & \multicolumn{2}{|c|}{ 3. Recipient's Catalog No. } \\
\hline \multicolumn{2}{|c|}{$\begin{array}{l}\text { 4. Title and Subtitle } \\
\text { Evaluating Innovative Financing Mechanisms for the California } \\
\text { High-Speed Rail Project }\end{array}$} & \multicolumn{2}{|l|}{ 5. Report Date } \\
\hline \multicolumn{2}{|c|}{$\begin{array}{l}\text { 7. Authors } \\
\text { Shailesh Chandra, Timothy Thai, Vivek Mishra, Princeton Wong }\end{array}$} & \multicolumn{2}{|c|}{$\begin{array}{l}\text { 8. Performing Organization Report } \\
\text { CA-MTI-2047 }\end{array}$} \\
\hline \multicolumn{2}{|c|}{$\begin{array}{l}\text { 9. Performing Organization Name and Address } \\
\text { Mineta Transportation Institute } \\
\text { College of Business } \\
\text { San José State University } \\
\text { San José, CA } 95192-0219\end{array}$} & \multicolumn{2}{|c|}{$\begin{array}{l}\text { 11. Contract or Grant No. } \\
\text { ZSB12017-SJAUX }\end{array}$} \\
\hline $\begin{array}{l}\text { 12. Sponsoring Agency Name and Address } \\
\text { State of California SB1 2017/2018 } \\
\text { Trustees of the California State Univers } \\
\text { Sponsored Programs Administration } \\
401 \text { Golden Shore, } 5^{\text {th }} \text { Floor } \\
\text { Long Beach, CA } 90802\end{array}$ & & \multicolumn{2}{|c|}{ 14. Sponsoring Agency Code } \\
\hline \multicolumn{4}{|l|}{ 15. Supplemental Notes } \\
\hline \multicolumn{4}{|c|}{$\begin{array}{l}\text { 16. Abstract } \\
\text { Millions of dollars are involved in high-speed rail (HSR) infrastructure construction and maintenance. Large-scale projects } \\
\text { like HSR require funding from a variety of avenues beyond those available through public monies. Although HSR serves the } \\
\text { general public's mobility needs, any funds (whether State or Federal) flowing from the public exchequer usually undergo strict } \\
\text { review and scrutiny. Funds from public agencies are always limited, making such traditional financing mechanisms } \\
\text { unsustainable for fulfilling HSR's long-term operational and maintenance cost needs-on top of initial costs involved in } \\
\text { construction. Therefore, any sustainable means of financing HSR projects would always be welcome. This research presents } \\
\text { an alternate revenue generation mechanism that could be sustainable for financing HSR's construction, operation, and } \\
\text { maintenance. The methodology involves determining key HSR stations, which, after development and improvement, could } \\
\text { significantly add value to businesses and real estate growth. Any form of real estate taxes levied on properties surrounding such } \\
\text { stations could substantially support the HSR project's funding needs. In this research, a bi-objective optimization problem is } \\
\text { posed in conjunction with a Pareto-optimal front framework to identify those key stations. With } 28 \text { California HSR stations } \\
\text { used as an example, it was observed that the four proposed HSR stations in Fullerton, Millbrae-SFO, San Francisco Transbay } \\
\text { Terminal, and San Diego would be excellent candidates for development. Their development could increase the economic } \\
\text { vitality of surrounding businesses. The findings could serve as valuable information for California HSR authorities to focus on } \\
\text { developing key stations that would generate an alternate funding source for an HSR project facing funding challenges. }\end{array}$} \\
\hline $\begin{array}{l}\text { 17. Key Words } \\
\text { High-speed rail, station, optimization, } \\
\text { business, cost, accessibility }\end{array}$ & $\begin{array}{l}\text { 18. Distribution Statement } \\
\text { No restrictions. This documen } \\
\text { Technical Information Service }\end{array}$ & $\begin{array}{l}\text { ailable to the pub } \\
\text { ngfield, VA } 22161\end{array}$ & The National \\
\hline $\begin{array}{l}\text { 19. Security Classif. (of this report) } \\
\text { Unclassified }\end{array}$ & $\begin{array}{l}\text { 20. Security Classif. (of this page) } \\
\text { Unclassified }\end{array}$ & $\begin{array}{l}\text { 21. No. of Pages } \\
25\end{array}$ & 22. Price \\
\hline
\end{tabular}

Form DOT F 1700.7 (8-72) 
Copyright (C) 2021

\section{by Mineta Transportation Institute}

All rights reserved.

DOI: $10.31979 / \mathrm{mti} .2021 .2047$

\footnotetext{
Mineta Transportation Institute

College of Business

San José State University

San José, CA 95192-0219

Tel: (408) 924-7560

Email: mineta-institute@sjsu.edu

transweb.sjsu.edu/research/2047
} 


\section{ACKNOWLEDGMENTS}

The research team would like to thank MTI for the funding received to conduct this research.

Cover Photo by Reginar (Usplash). 


\section{CONTENTS}

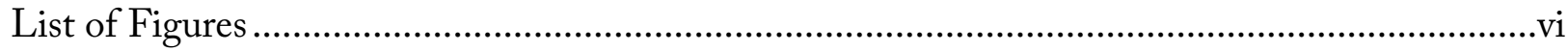

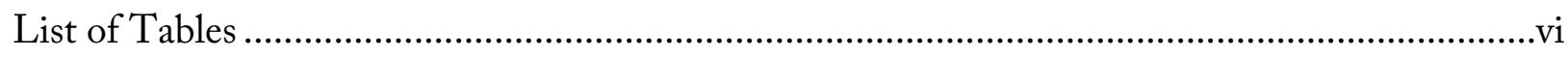

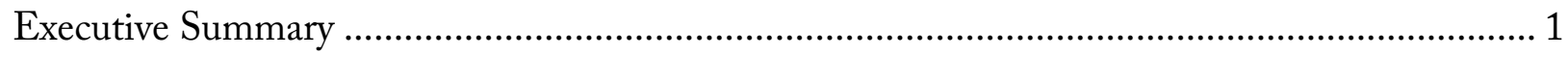

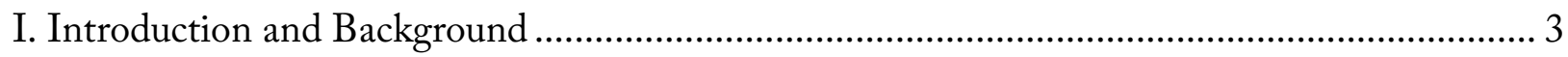

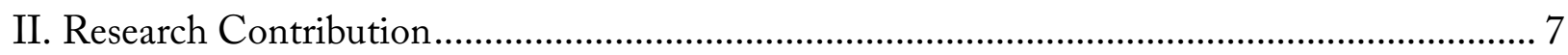

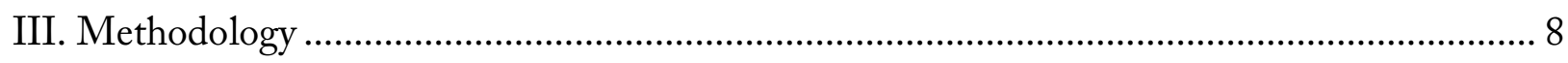

3.1 Maximizing Revenue Potential ................................................................... 8

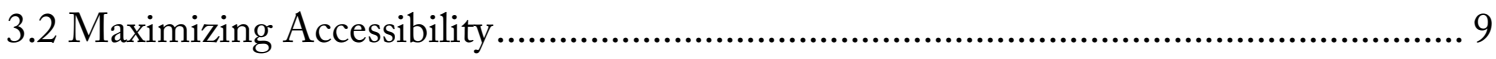

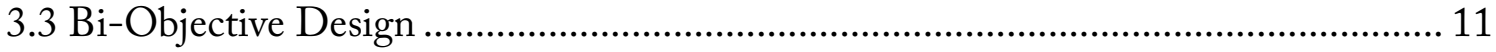

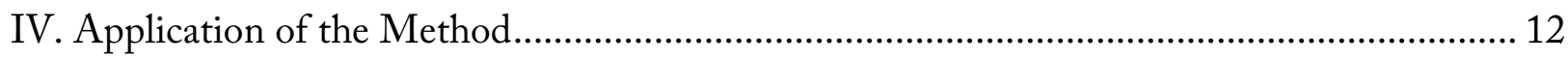

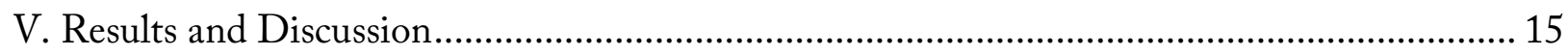

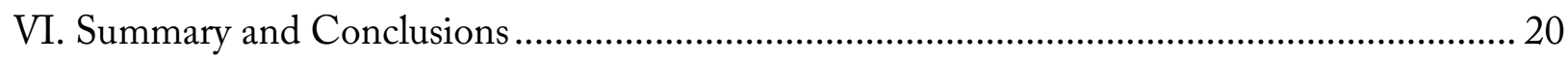

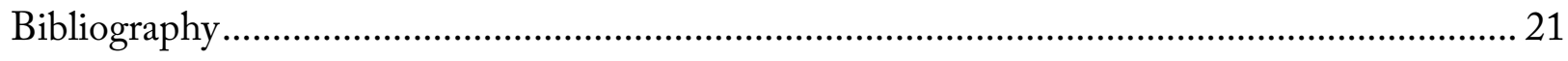

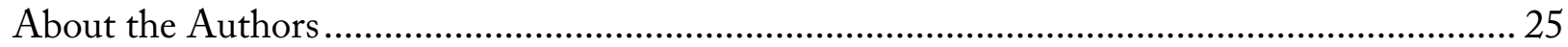




\section{LIST OF FIGURES}

Figure 1. Spatial Distribution of Property Tax Surrounding the Proposed

High-Speed Rail Stations in California

Figure 2. Spatial Distribution of the Estimated Total Employment for the Year 2020 within a Quarter-Mile Radius of the Proposed High-Speed

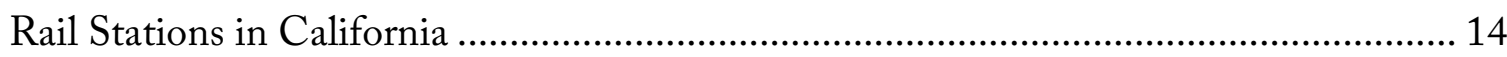

Figure 3. Spatial Variation in the Revenue Potential of Proposed HSR Stations in CA ............ 17

Figure 4. Spatial Variation in the Percentage Change in Potential Accessibility

of the Proposed HSR Stations in CA ………………….......................................... 18

Figure 5. Pareto-Optimal Solution Representation for a Bi-Objective

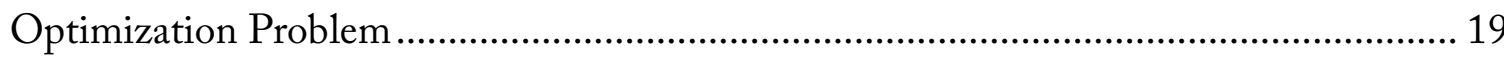

\section{LIST OF TABLES}

Table 1. Examples of Funding Sources for High-Speed Rail (HSR) 


\section{Executive Summary}

Funding for large-scale infrastructure projects often involves partnerships from public entities at the local, regional, and/or national levels. However, unforeseen challenges thwart full-fledged financing of projects that use public funds. This is because public funds are often politically invested, temporal, tax-dependent, and sensitive to the public agency's economic health. Largescale projects like high-speed rail (HSR) require funding from a variety of avenues beyond those available through public monies. Although HSR serves the general public's mobility needs, any funds (whether State or Federal) flowing from the public exchequer usually undergo strict review and scrutiny. Funds from public agencies are always limited, making such traditional financing mechanisms unsustainable for fulfilling HSR's long-term operational and maintenance cost needs-on top of initial costs involved in construction. Therefore, any sustainable means of financing HSR projects would always be welcome.

This research presents an alternate revenue generation mechanism that could be sustainable for financing HSR construction, operation, and maintenance. The methodology involves identifying key HSR stations, which, after development and improvement, could significantly add value to businesses and real estate growth. Any form of real estate taxes levied on properties surrounding such stations could substantially support the HSR project's funding needs. However, research shows that not every HSR station promotes increased economic activity, and impacts vary based on the station's city. Therefore, it will be useful to know which stations could focus on development and improvement to cause increased economic activity in their surrounding areas for both revenue generation and growth in economic potential.

In this research, a bi-objective optimization problem is posed in conjunction with a Pareto-optimal front framework to identify those key stations. The first objective involves maximizing the revenue potential and the second objective involves maximizing the percentage change in potential accessibility. The Pareto-optimal front is defined as a set of non-dominated solutions that is considered as optimal. A non-dominated solution in the Pareto-optimal front is a set of objective function values that are not dominated by values of any other pair of objective functions in the solution set.

With 28 proposed California HSR stations used as a sample set, it was observed that the four proposed HSR stations in Fullerton, Millbrae-SFO, San Francisco Transbay Terminal, and San Diego would be excellent candidates for development. Their development could increase the economic vitality of surrounding businesses. These four stations are located at some of California's densest employment hubs and would become well connected once HSR becomes fully operational in the state.

Out of the four non-dominated stations proposed as solutions, the proposed Millbrae-SFO and San Francisco Transbay Terminal stations are located very close to each other. The San Francisco Transbay Terminal station is proposed to be the terminal station of the HSR line. The proposed 
Millbrae station already serves Caltrain and Bay Area Rapid Transit (BART) modes near San Francisco International Airport (SFO). The enhanced transit connectivity provided by the HSR station at Millbrae-SFO will encourage surrounding station area development and promote economic growth in conjunction with other existing transportation modes. Currently, a draft environmental document is underway for determining the Millbrae-SFO station location and alignment. The proposed HSR station in San Francisco is the Salesforce Transit Center (STC), which will serve 11 transportation systems. This proposed HSR station in San Francisco has been environmentally cleared by the Transbay Joint Powers Authority (TJPA). Fullerton's proposed station is currently under evaluation on the Los Angeles to Anaheim HSR project section. The proposed HSR station of San Diego is to be located close to the San Diego International Terminus. Thus, the station will facilitate access to the air transportation mode once HSR becomes operational.

The findings could serve as valuable information prompting California HSR authorities to develop the four aforementioned vital stations that could generate an alternate funding source for an HSR project facing funding challenges. 


\section{Introduction and Background}

High-speed rail (HSR) promotes a region's economic integration by enhancing competitiveness and achieving greater cohesion among people (Cheng et al., 2015). However, in the United States, the full potential of HSR still needs to be realized. Current progress in HSR development in the country has either been slow or uncertain. Examples of the HSR development have been in Texas that would connect Houston and Dallas and the California HSR program proposed to connect at least 26 different urban and rural cities (Geffen, 2018). Findings suggest that the HSR is needed in the United States to connect economically disadvantaged regions (Chandra and Vadali, 2014). However, major challenges need to be overcome in support of HSR projects, including planning its alignment without disputes/lawsuits, land acquisitions, environmental clearance, etc. Among these challenges, the availability of capital funds for HSR infrastructure construction, operations, and maintenance is often the most crucial.

Funding for large-scale infrastructure projects often involves partnerships with public entities at the local, regional, and/or national levels. However, unforeseen challenges thwart full-fledged funding of projects that use public funds. This is because public funds are often politically invested, temporally limited, tax-dependent, and sensitive to the public agency's economic health. As a result, funds provided primarily by public agencies often run short and hinder the timely completion of a large-scale infrastructure project. California's HSR project is one such example (Government Technology, 2020). Therefore, alternative sources of funding for HSR projects are always welcome.

The HSR serves as a fast transportation mode facilitating mobility, promoting safety, and increasing intermodal connectivity - very conducive for thriving businesses around its stations in cities (Diao, 2018). Several studies show that upgrades and improvements of rail-related infrastructure (such as station development, grade separations, etc.) have increased real estate value, and businesses prosper around those improvements (Cao and Porter-Nelson, 2016; Aldrete et al., 2018). However, guidance on determining the optimal location of such improvements to tap into the economic benefits is still missing in the research.

Projects that have limited funding but are deemed important use innovative methods like the Transportation Reinvestment Zone (TRZ), similar to value capture, to pay off capital loans. TRZ has been emerging as an alternative revenue generation tool for managing large-scale transportation improvement projects in states like Texas and elsewhere in the United States (Aldrete et al., 2018).

Several existing studies have evaluated economic growth potential to determine the economic benefits available to a region through rail station and transit-oriented developments (Zhang and Yen, 2020; Murakami and Cervero, 2010; Belzer et al., 2011). A vast majority of studies mention access improvements (as an indicator of economic growth potential) to justify the construction or revitalization of transportation facilities in a region (Gutiérrez, 2001; Chandra and Vadali, 2014). 
Several studies provide evidence of the connection between HSR introduction in a region and property values. Hensher and Mulley (2012) examine the impact of accessibility delivered by HSR on land and property values and suggest that HSR can affect land values to varying degrees, including price premiums and price reductions. Earlier, Cervero and Duncan (2002) also identified the varying degrees of benefits and premiums to residential properties, especially for large apartments within a quarter-mile distance of rail transit stations. Another study by Shi and Guo (2009) on the Shanghai South Railway Station in China also concluded that impacts on housing prices were mainly experienced within a mile of proximity to the rail stations.

Literature on heavy rail transit from South Korea, the Netherlands, and Germany has corroborated the positive impacts of rail on residential housing prices (Bae et al., 2003; Debrezion et al., 2010; Brandt and Maennig, 2012). Earlier, Diaz (1999) identified a variety of factors that increase property values around rail transit. One of the factors was the increase in accessibility brought about by the new transit investment. A study by Ryan (1999) showed a relationship between transportation facilities and property values indicated that the use of travel time as a measure of accessibility gave the expected inverse relationships between access to transportation facilities and property values. However, the results for travel distance indicated mixed property value effects. Kilpatrick et al. (2007) examined two situations of transit corridors: one with both access benefits and negatives, and another without access benefit. The study criticized prior studies that only consider the overall impact on affected properties, combining positive public good and the negative externality, of the transit. The findings revealed that mere proximity to the corridor without direct access has a negative effect on housing values.

A study by Chen and Haynes (2015) showed that the Beijing-Shanghai HSR line increased the housing values in medium and small cities; however, negligible impacts were noted in larger capital cities. Edwards (2012) had found similar results for regional Australian towns traversed by the HSR, causing agglomeration benefits and benefits to cities that had a HSR station. Studies on HSR in Taiwan (Andersson et al., 2010) and China's large cities like Shanghai and Minhang (Rungskunroch et al., 2020), along with a Delphi survey by Loukaitou-Sideris et al. (2012), concluded that the impacts of HSR depend on the context and circumstances such as the extent of regional accessibility, city development plans, and so on.

For HSR projects, careful consideration is required during the planning phase because of the financial hurdles and the time it takes to start service and operations. The ability to create a financial plan is essential to the construction of the HSR. Several examples of partnerships involve shared funding commitments between public and private entities for HSR projects. The appeal of socio-economic returns allows governments to provide public funding, while the appeal of financial return allows private investors to provide private funding. The trans-European HSR project had multiple forms of funding measures (such as loans) for their member states from the TransEuropean Transport Networks (TEN) budget line, as well as a European Investment Bank (EIB) and European Investment Fund (EIF) loan (Roll and Verbeke, 1998). It is common for the Chinese government to provide financial assistance for HSR infrastructure construction at about 
$¥ 600$ billion RMB (about $\$ 91$ billion USD) per year (Long and Zhang, 2019). As for India, the HSR line that will connect Mumbai and Ahmedabad will cost around ₹977 billion INR (about $\$ 13$ billion USD), although the external sponsor, the Japan International Cooperation Agency (JICA), will contribute almost $80 \%$ of the project costs (Raghuram and Udayakumar, 2016). The funding for the Taiwan High Speed Rail (THSR) came from two sources: shareholder equity accounted for $20 \%$, and local banking groups took care of the remaining $80 \%$ (Cheng, 2010). Table 1 presents a compilation of funding sources for some examples of HSR projects in various European jurisdictions, plus California. 
Table 1. Examples of Funding Sources for High-Speed Rail (HSR)

\begin{tabular}{|c|c|c|c|c|c|}
\hline Name & Location & Funding & $\begin{array}{l}\text { Amount } \\
\text { (USD equivalent) }\end{array}$ & $\begin{array}{l}\text { Year } \\
\text { Reported }\end{array}$ & Reference(s) \\
\hline $\begin{array}{l}\text { Lisbon-Madrid } \\
\text { high-speed rail line }\end{array}$ & Portugal & $\begin{array}{l}\text { European Regional } \\
\text { Development Fund }\end{array}$ & $\begin{array}{l}€ 205.1 \mathrm{~m} \\
(\$ 239.41 \mathrm{~m})\end{array}$ & 2016 & TPF, 2020 \\
\hline $\begin{array}{l}\text { High-speed rail } \\
\text { in Italy } \\
\text { (Turin-Lyon line) }\end{array}$ & $\begin{array}{l}\text { Italy and } \\
\text { France }\end{array}$ & European Union & $\begin{array}{l}40 \% \text { of } € 26 \text { billion } \\
(\$ 12.14 \mathrm{~b})\end{array}$ & Mid 2019 & $\begin{array}{l}\text { Railway } \\
\text { Technology, } \\
2020\end{array}$ \\
\hline $\begin{array}{l}\text { Brescia High } \\
\text { Speed Line }\end{array}$ & Italy & $\begin{array}{l}\text { European Commissioner } \\
\text { for Transport }\end{array}$ & $\begin{array}{l}€ 1.7 \text { billion } \\
\text { (\$1.98b) }\end{array}$ & $\begin{array}{l}\text { December } \\
2008\end{array}$ & $\begin{array}{l}\text { Railway Gazette } \\
\text { International, } \\
2020\end{array}$ \\
\hline RailJet & Austria & $\begin{array}{l}\text { Liechtenstein }(33.75 \%) \\
\text { and Austria } \\
\text { (Österreichische } \\
\text { Bundesfinanzierungsage } \\
\text { ntur, OeBFA) }\end{array}$ & $\begin{array}{l}€ 63 \text { million } \\
\text { [Liechtenstein } \\
(\$ 73.54 \mathrm{~m})] \\
\text { and the remainder } \\
\text { from Austria }\end{array}$ & 2016 & $\begin{array}{l}\text { International } \\
\text { Railway Journal, } \\
2020\end{array}$ \\
\hline $\begin{array}{l}\text { High Speed Train } \\
\text { Sweden (SJ AB) }\end{array}$ & Sweden & $\begin{array}{l}\text { NIB (Nordic Investment } \\
\text { Bank) and the Swedish } \\
\text { passenger train operator }\end{array}$ & $\begin{array}{l}€ 144 \text { million } \\
(\$ 170 \mathrm{~m})\end{array}$ & 2020 & $\begin{array}{l}\text { Nordic } \\
\text { Investment Bank, } \\
2020\end{array}$ \\
\hline $\begin{array}{l}\text { High-Speed Train } \\
\text { Madrid-Castilla La } \\
\text { Mancha- } \\
\text { Comunidad } \\
\text { Valenciana-Region } \\
\text { of Murcia }\end{array}$ & Spain & $\begin{array}{l}\text { EU's European Regional } \\
\text { Development Fund }\end{array}$ & $\$ 51.5$ million & $2007-2013$ & $\begin{array}{l}\text { European } \\
\text { Commission, } \\
\text { 2020a }\end{array}$ \\
\hline $\begin{array}{l}\text { HST railway station } \\
\text { in Guillemins }\end{array}$ & Belgium & $\begin{array}{l}\text { European Regional } \\
\text { Development Fund } \\
\text { (ERDF) }\end{array}$ & $\$ 53.36$ million & 2009 & $\begin{array}{l}\text { European } \\
\text { Commission, } \\
2020 b\end{array}$ \\
\hline \multirow[t]{3}{*}{$\begin{array}{l}\text { California } \\
\text { High-Speed Rail } \\
\text { (proposed) }\end{array}$} & $\mathrm{CA}$ & $\begin{array}{l}\text { American Recovery and } \\
\text { Reinvestment Act of } \\
2009 \text { (ARRA) }\end{array}$ & $\$ 2.5$ billion & 2009 & $\begin{array}{l}\text { California High- } \\
\text { Speed Rail } \\
\text { Authority, 2020c }\end{array}$ \\
\hline & & $\begin{array}{l}\text { Transportation, Housing } \\
\text { and Urban Development } \\
\text { grant } 2010\end{array}$ & $\$ 939$ million & 2010 & \\
\hline & & Cap-and-Trade Program & $\begin{array}{l}25 \text { percent of the } \\
\text { annual proceeds }\end{array}$ & 2014-2030 & \\
\hline
\end{tabular}




\section{Research Contribution}

Public authorities seek sustained funds to complete large-scale infrastructure projects and studies show that for rail transit, revenue collected from property tax collections from surrounding parcels of rail stations could fulfill the funding needs. However, there is no clear guidance on the procedures that the public authorities can adopt to identify one or more key HSR stations for development and subsequent revenue generation. Guidance is needed to help reduce the loans or debts incurred in the construction of HSR infrastructure. Several competing factors and objectives need to be considered in this process. A multi-objective optimization approach is needed for this purpose.

This research proposes a bi-objective optimization methodology by incorporating the 'value capture' and 'attractiveness' potential of stations considered for development. A station that would yield the largest values for both the value capture and attractiveness objectives should be selected for development. The value capture potential is estimated by maximizing the revenue potential whereas the attractiveness is calculated by maximizing the percentage change in the station's potential accessibility. Subsequently, a Pareto-optimal front is constructed by comparing the two objective functions across candidate stations being analyzed. The Pareto-optimal front is the set of non-dominated solutions that is considered as optimal. A non-dominated solution in the Pareto-optimal front is a set of objective function values that are not dominated by values of any other pair of objective functions in the solution set.

Stations that rank highest in revenue collection through value capture and potential accessibility in terms of attractiveness form the front. The methodology can be used to study the case of California's HSR, which urgently needs to attract businesses around its key proposed stations and increase the revenue potential, and those stations becoming promising as hubs of economic activity. This can motivate continued investment in HSR to promote its completion and its successful operation to benefit Californians.

Substantial resources have already gone into funding the HSR program-almost ten years of effort-and an unfinished project could lead to the loss of jobs that have been sustained by the HSR program. Thus, innovative funding mechanisms that have often proved to be effective for large-scale infrastructure projects could be evaluated for California's HSR completion. There are limited literatures on tools to leverage funds from evaluating all aspects of economic benefits accrued from HSR construction and completion. Alternative financing sources, such as value capture, can be explored to fund California's HSR program, which should be achieved through sustainable and innovative means. The findings from this proposed research would help decision makers determine benefits that have not yet been thought of being harnessed if completion of HSR segments is carried out at strategic locations to connect critical stations and making HSR operational. The methodology presented in this research can be used to achieve this purpose. The goal is to determine those HSR stations that could trigger increases in revenue potential and accessibility to generate further economic activity surrounding the stations. The methodology 
proposed in this research can also be applied to study other HSR projects that are facing similar funding challenges.

\section{Methodology}

A proposed HSR station can be analyzed for its potential to produce economic and financial benefits upon development and improvement. These improvements could attract businesses to the vicinity, ultimately leading to land value increase surrounding the station. The expected outcome due to the improvement, therefore, supports the analysis for their revenue generation potential and the extent of economic activity (e.g., employment growth) in their vicinity.

Research shows that not every HSR station promotes increased economic activity, and impacts vary based on the station's city (Chen and Haynes, 2015). Therefore, it will be useful to know which stations could be targeted for development and improvement to cause increased economic activity in the stations' surroundings for revenue generation as well as growth in economic potential. Such an investigation would also provide information on the extent and magnitude of these economic impacts once the key stations become operational for service.

Therefore, in this research, a methodology is proposed to solve a bi-objective optimization problem. The optimization problem seeks to identify one or more HSR stations that have the largest increase in revenue generated from tax collected from the real estate properties surrounding the station and the largest increase in the station's potential accessibility value. However, this might not be possible: i.e., a station could have the largest potential accessibility increase but its revenue generation could lag. For a better understanding of the interaction between the potential accessibility and revenue generation, formulations are developed for each of the two objectives as follows.

\subsection{Maximizing Revenue Potential}

Value capture is commonly used in Europe and the United States for revenue generation to fund transit (Salon et al., 2019). For example, existing laws in California provide guidance (and regulation) in funding infrastructure projects; a tax increment tool called the Enhanced Infrastructure Financing District (EIFD), similar to value capture, is used for economic development (League of California Cities, 2019). EIFD authorizes a city's legislative body or a county within the state to use tax increment financing (TIF) to finance various infrastructure improvement projects within its jurisdiction. EIFD enables cities to provide a stable funding source for infrastructure projects, exert leverage, and induce private investments. For an HSR station, TIF-based EIFD would depend on tax collected from surrounding properties. Therefore, stations with high property taxes collected from parcels surrounding the station will be favored for development and improvement. 
The first objective function for the optimization problem aims to maximize the total property tax from every parcel within a given threshold distance from a station. Thus, the objective function for maximizing revenue generated, $\max \left(R P_{i}\right)$, can be written as

\section{Objective function 1: Maximization of revenue generated}

$$
\max \left(R P_{i}\right)=\sum_{k} a_{i, k}^{D}, \text { and } k \in P
$$

where

$a_{i, k}^{D}=$ property tax collected from parcel $k$ within a (threshold) distance $D$ from station $i$

$P=$ total number of parcels.

\subsection{Maximizing Accessibility}

Accessibility is often used as an indicator for the economic potential of a location (Chandra and Vadali, 2014). In this research, a proposed HSR station's economic potential is assessed using its accessibility, which would entail future growth in surrounding property values. The formula for accessibility adopted in this research is based on the potential accessibility derived by Chandra and Mazin (2020). Therefore, the potential accessibility $\left(P A_{i}\right)$ of a HSR station $i$ is expressed as

$$
P A_{i}=\sum_{j} \frac{b_{i, j}}{F\left(I_{i, j}\right)}, i \neq j \text { and } j \in N
$$

where

$b_{i j}=$ total riders boarding the origin station $i$ to reach destination station $j$

$N=$ total number of stations in the rail transportation network

$F\left(I_{i, j}\right)=$ the impedance function with $I_{i, j}$ could be assumed to be the distance, travel time, energy cost etc. and is incurred from a given origin station $i$ to a destination station $j$.

The function assumes a gravity-based form proposed by Hansen (1959) with a decay parameter $\alpha$, and thus, the function can be simply written as

$$
F\left(I_{i, j}\right)=I_{i, j}^{\alpha}
$$

The decay parameter $\alpha$ in Eq. (3) indicates the variation in accessibility between an origin $i$ and a destination $j$. In other words, the value of the decay parameter determines how far rail commuters would travel from the origin $i$ to destination $j$ using a mode. In practice, the decay parameter needs travel demand data for calibration and estimation. However, as a rule of thumb, the decay parameter value is often assumed to be 1 in the absence of travel demand data (Gutiérrez, 2001).

The accessibility formula shown in Eq. (2) describes a direct relationship between commuters boarding an origin station and traveling to another destination station. In the absence of exact ridership comparison between stations, the number of commuters using the HSR can be assumed to be proportional to the magnitude of employment from industries within a given threshold 
distance around its stations. Numerous studies have also shown that transit ridership is proportional to the population size (Liu et al., 2016; Hiramatsu, 2018). Therefore, in the absence of actual ridership data for Eq. (1), population or employment around a station can be used for an approximation.

With the further assumption that the average speed of the HSR is constant between any two stations, the impedance function in Eq. (2) would be directly proportional to the average travel time taken between the stations. Thus, the accessibility for a station in Eq. (2) can be rewritten as

$P A_{i}=\sum_{j} \frac{b_{i, j}}{t_{i, j}{ }^{\alpha}}, i \neq j$ and $i, j \in N$

where $t_{i, j}$ is the travel time with HSR between the station $i$ (as origin) and station $j$ (as destination) along the rail network.

A station that has the largest value for potential accessibility change (as a percentage) should be selected for development and improvement. This would entail sustained economic growth around the station. In this research, the percentage change in $P A_{i}$ for a station $i$ before and after an improvement is used to evaluate the largest value of potential accessibility change. The percentage change in $P A_{i}$ for a station $i$ is calculated as future year $P A_{i}$ ('after' scenario with the HSR line) minus base year $P A_{i}$ ('before' scenario without the HSR line), and the difference is divided by base year $P A_{i}$ ('before' scenario without the HSR line). The percentage change in $P A_{i}$ is obtained by multiplying the ratio by 100 . Therefore, the second objective function maximizing the percentage change in potential accessibility of a station $i, \max \left(\Delta P A_{i}\right)$, is expressed as

\section{Objective function 2: Maximization of potential accessibility}

$$
\max \left(\Delta P A_{i}\right)=\left(\frac{\sum_{j} \frac{b_{j}^{\text {after }}}{\left(t_{i, j}^{\text {after }, \text { HSR }}\right)^{\alpha}}-\sum_{j} \frac{b_{j}^{\text {before }}}{\left(t_{i, j}^{\text {before }, \text { highway }}\right)^{\alpha}}}{\sum_{j} \frac{b_{j}^{\text {before }}}{\left(t_{i, j}^{\text {before, highway }}\right)^{\alpha}}}\right) \times 100, i \neq j \text { and } i, j \in N
$$

where

$$
\begin{aligned}
& b_{j}^{\text {after }}=\text { employment surrounding a HSR station } j \text { after HSR is operational } \\
& b_{j}^{\text {before }}=\text { employment surrounding a HSR station } j \text { before HSR is operational } \\
& t_{i, j}^{\text {after,HSR }}=\text { travel time from station } i \text { to station } j \text { with HSR operational } \\
& t_{i, j}^{\text {before, highway }}=\text { travel time from a city with station } i \text { to a city with station } j \text { using highway. }
\end{aligned}
$$

This method of evaluating percentage change in $P A_{i}$ with normalization is justified in studies by Chandra and Mazin (2020) and Chandra and Vadali (2014). In this way, each station $i$ is evaluated for its attractiveness resulting from the increased employment weighted access to stations. 


\subsection{Bi-Objective Design}

With the two objective functions defined in Eqs. (1) and (5), the next step is to determine stations that satisfy both functions. Therefore, solutions are sought for the bi-objective optimization problem with a general formulation adapted from Brisset and Gillon (2015). Solutions are presented below for the two objective functions:

$$
\begin{array}{ll}
\operatorname{maximize} & \mathbf{F}(\mathbf{x})=\left[f_{1}(\mathbf{x}), f_{2}(\mathbf{x})\right] \\
\text { subject to: } \quad & g_{r}(\mathbf{x}) \leq 0 \quad r=1, \ldots, n_{r} \\
& h_{s}(\mathbf{x})=0 \quad s=1, \ldots, n_{s}
\end{array}
$$

with $\mathbf{x}=\left[x_{1}, \ldots, x_{c}, \ldots, x_{n}\right]$ and $x_{c}^{l} \leq x_{c} \leq x_{c}^{u}$

where

$\mathbf{F}=$ set of two objective functions

$g_{r}(\mathbf{x})=$ total $n_{r}$ inequality constraints involving the variables $\mathbf{x}$ used in revenue potential and percentage change in accessibility

$h_{s}(\mathbf{x})=$ total $n_{s}$ equality constraints involving the variables $\mathbf{x}$ used in revenue potential and percentage change in accessibility

$\mathbf{x}=$ vector containing $n$ variables (that make up the revenue potential and percentage change in accessibility formula)

$x_{c}^{l}=$ lower limit to the variable $x_{c}$

$x_{c}^{u}=$ upper limit to the variable $x_{c}$.

The variable $n$ is the number of stations as the elements of vector $\mathbf{x}$. A station can be included in the Pareto front if it has particular values for revenue potential and accessibility and dominates other stations for these two values. The following condition should be satisfied:

$f_{i}\left(\mathbf{x}_{1}\right) \leq f_{i}\left(\mathbf{x}_{2}\right) \forall i \in\{1, \ldots, m\}$ and $\exists j \in\{1, \ldots, m\} \mid f_{j}\left(\mathbf{x}_{1}\right)<f_{j}\left(\mathbf{x}_{2}\right)$

A station is considered non-dominated or Pareto-optimal if no other station dominates it across the two objective functions. All non-dominated stations are on the Pareto front. Thus, one or more stations that fall into the Pareto front, as per the condition imposed by Eq. (7), can determine the outcome of the bi-objective optimization approach expressed using Eq. (6). This means a station that falls on the Pareto front qualifies to be selected for improvement and development to satisfy the two objective functions: i.e., maximization of the potential accessibility and revenue generation. 


\section{Application of the Method}

California HSR has recently faced uncertainty in funding from its federal partner, the Federal Railroad Administration (FRA, 2019). In May 2019, the FRA cancelled its entire funding initially intended for the completion of the HSR program. The primary reason cited was the slow progress of the project, and it was also understood as a response to the Governor's announcement that only a short segment section of the HSR line would be completed linking Merced and Bakersfield in the state's Central Valley.

The county property tax is used to evaluate revenue potential as expressed in objective function 1 (i.e. maximizing revenue potential) of Eq. (1). In the absence of actual data needed for parcels' property taxes surrounding the stations, the median property taxes at the spatial level of counties are used as an approximation (data from Tax-rates.org, 2020).

Research shows that economic impacts due to transit improvement are primarily concentrated within a quarter-mile radius from the improvement (Cervero and Duncan, 2002). Therefore, parcels within a quarter-mile radius surrounding a station are considered for the total property tax calculation for objective function 1. The number of parcels surrounding an HSR station is collected from the 2014 California Parcels Dataset from Los Angeles County GIS webpage (LA County GIS, 2020).

The map in Figure 1 shows the proposed California HSR line and the stations with county median property taxes for properties surrounding each station. 
Figure 1. Spatial Distribution of Property Tax Surrounding the Proposed High-Speed Rail Stations in California

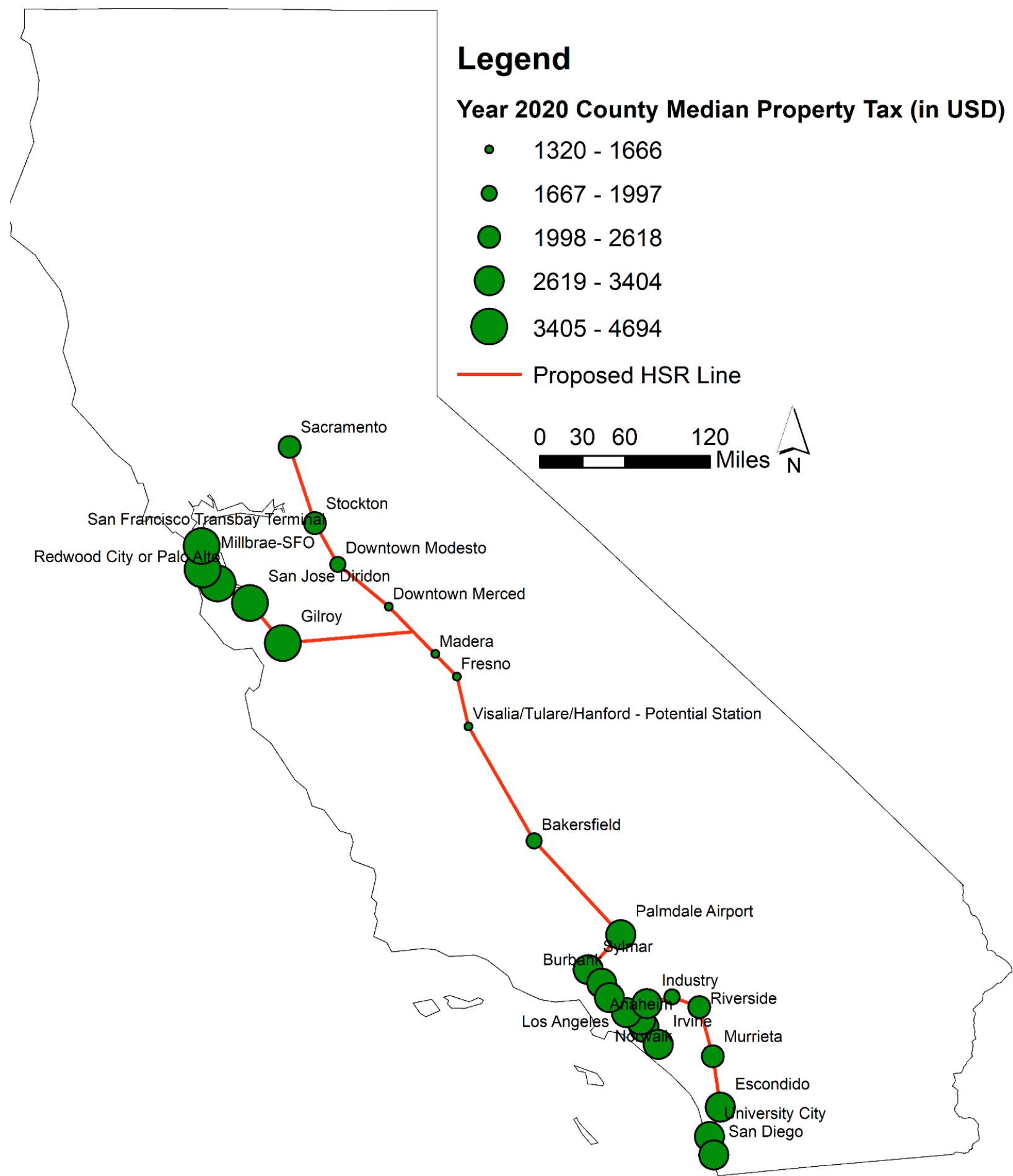

Employment data needed for the accessibility calculation in Eq. (5) are obtained from the Longitudinal Employer-Household Dynamics (LEHD) that provides the data years 2002 through 2017 (LEHD, 2020). The employment is extrapolated to 2020 with the anticipated HSR completion by 2022 . 
The map in Figure 2 shows the spatial variation in total employment for the year 2020 from all the industry sectors within a quarter-mile distance surrounding the proposed stations.

Figure 2. Spatial Distribution of the Estimated Total Employment for the Year 2020 within a Quarter-Mile Radius of the Proposed High-Speed Rail Stations in California

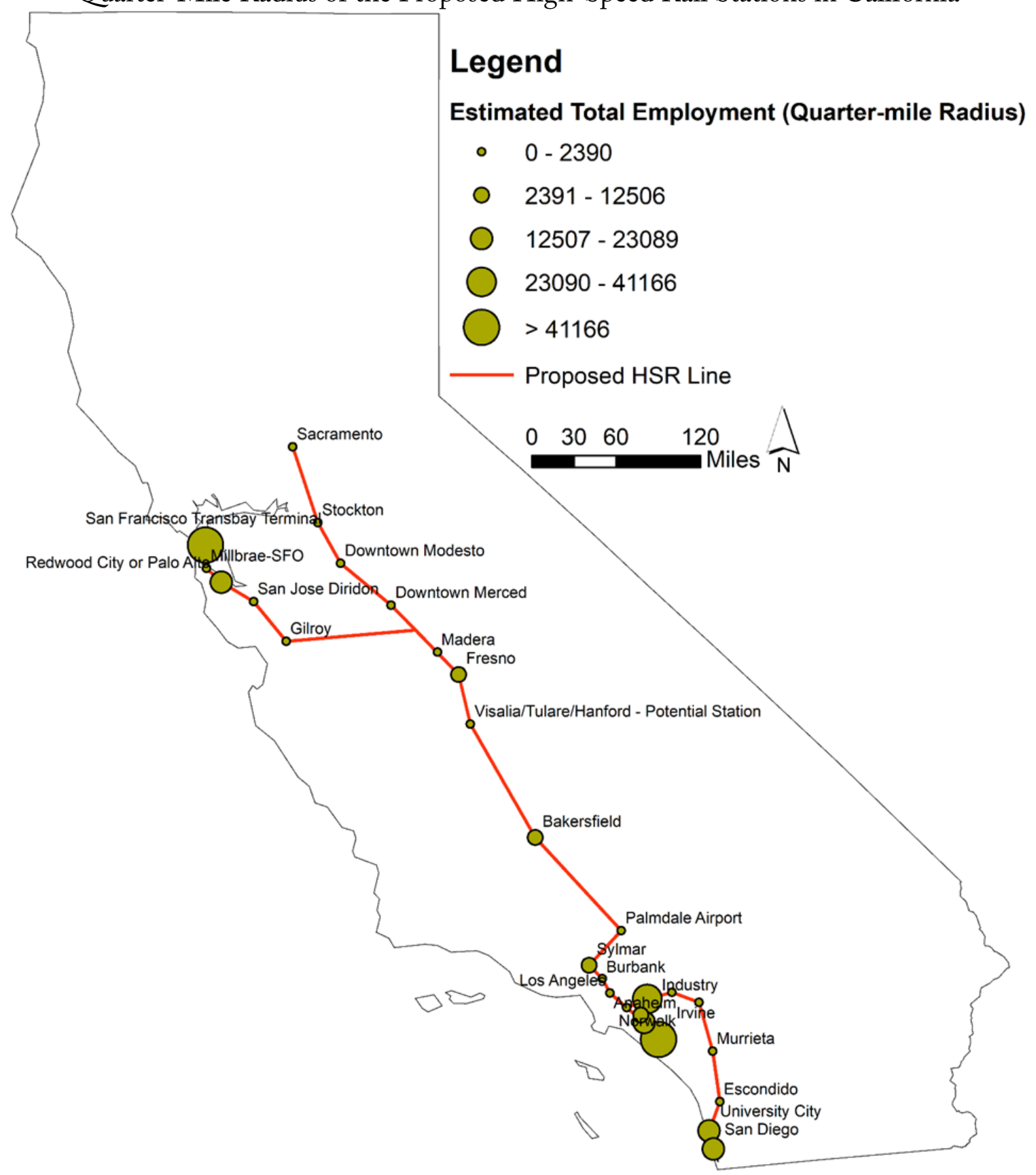

For impedance used in the accessibility formulation, the travel time skim matrix was obtained by dividing the distance between two stations by the assumed average speed of 200 miles per hour for the HSR (California High-Speed Rail, 2020b). The spatial maps for the HSR line and stations 
(total 28) shown in Figs. 1 and 2 were created using data from the California High-Speed Rail Authority (California High-Speed Rail, 2020a).

The data collected were finally used in determining the objective functions under Eqs. (1) and (5) and the outcome discussed in the next section.

\section{Results and Discussion}

The constraints used in the bi-objective optimization are such that both the revenue potential and the percentage change in potential accessibility are assumed to be positive. The analysis of the revenue potential using Eq. (1) shows that the proposed HSR stations of San Diego and San Francisco Transbay Terminal have the highest revenue potential among other proposed HSR stations. This is because the number of parcels within a quarter-mile distance is higher than the corresponding values for the other stations. Thus, if the focus is solely on generating revenue from property taxes under EIFD tax increment strategy, these two HSR stations should be developed and improved. The HSR stations of Millbrae-SFO and San Jose Diridon are the next two stations that should be considered for development and improvement for revenue generation purposes. (The spatial location of these four HSR stations is shown in Fig. 3.)

If the focus is on maximizing the potential accessibility (Eq. (5)), the stations of Fullerton, Millbrae-SFO, Norwalk, and Anaheim should be preferred for development and improvement. These four stations have the largest percentage change in potential accessibility. The high percentage change in accessibility value for these four stations can be attributed to their proximity to other stations with high employment within the quarter-mile distance threshold. (Fig. 4 shows the spatial variation in the percentage change in potential accessibility across the HSR stations.)

After obtaining the outputs from the bi-objective optimization, the authors constructed the Pareto-optimal front. The Pareto-optimal front presented in Figure 5 shows that the four proposed HSR stations of Fullerton, Millbrae-SFO, San Francisco Transbay Terminal, and San Diego stand out as the non-dominated solutions. These four stations are located at some of California's densest employment hubs and would become well-connected once HSR becomes fully operational in the state. Out of the four non-dominated stations, the proposed Millbrae-SFO and San Francisco Transbay Terminal stations are located very close to each other. The San Francisco Transbay Terminal station is proposed to be the end station of the HSR line.

The proposed Millbrae station already serves the Caltrain and Bay Area Rapid Transit (BART) modes near San Francisco International Airport (California High-Speed Rail Authority, 2020d). With the enhanced transit connectivity provided by the HSR station at Millbrae-SFO, the station will encourage surrounding station area development and promote economic growth in conjunction with other existing transportation modes. Currently, a draft environmental document is underway for determining the Millbrae-SFO station location and alignment. 
The proposed HSR station in San Francisco is the Salesforce Transit Center (STC), which will serve eleven transportation systems (California High-Speed Rail Authority, 2020e). The current status of this proposed HSR station in San Francisco is that it has been environmentally cleared by the Transbay Joint Powers Authority (TJPA).

Fullerton's proposed station is currently under evaluation on the Los Angeles to Anaheim Project Section (California High-Speed Rail Authority, 2020f). The proposed San Diego HSR station is to be located close to the San Diego International Terminus (California High-Speed Rail Authority, 2020g). Thus, the station will facilitate access to the air transportation mode once HSR becomes operational. 
Figure 3. Spatial Variation in the Revenue Potential of Proposed HSR Stations in CA

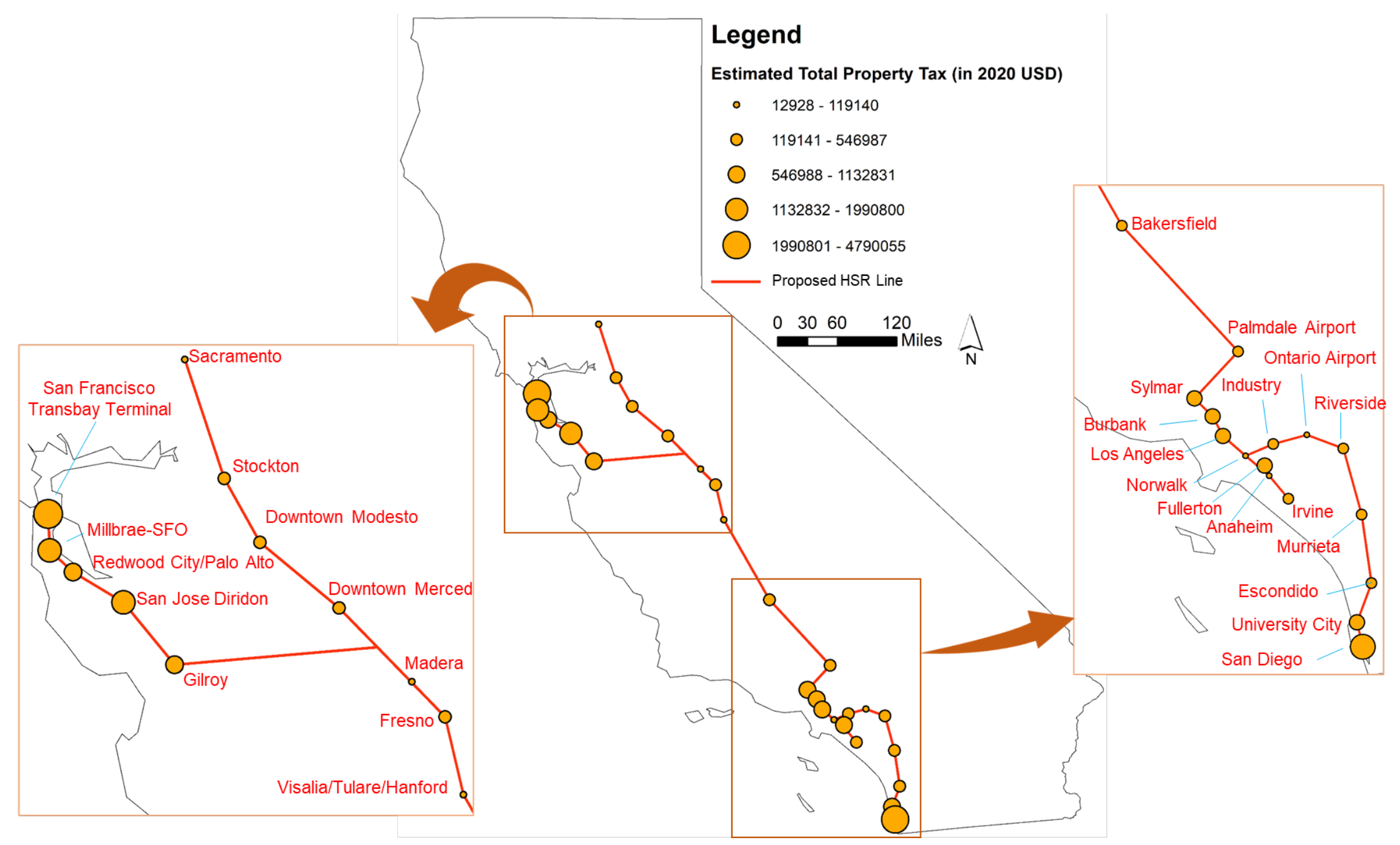


Figure 4. Spatial Variation in the Percentage Change in Potential Accessibility of the Proposed HSR Stations in CA

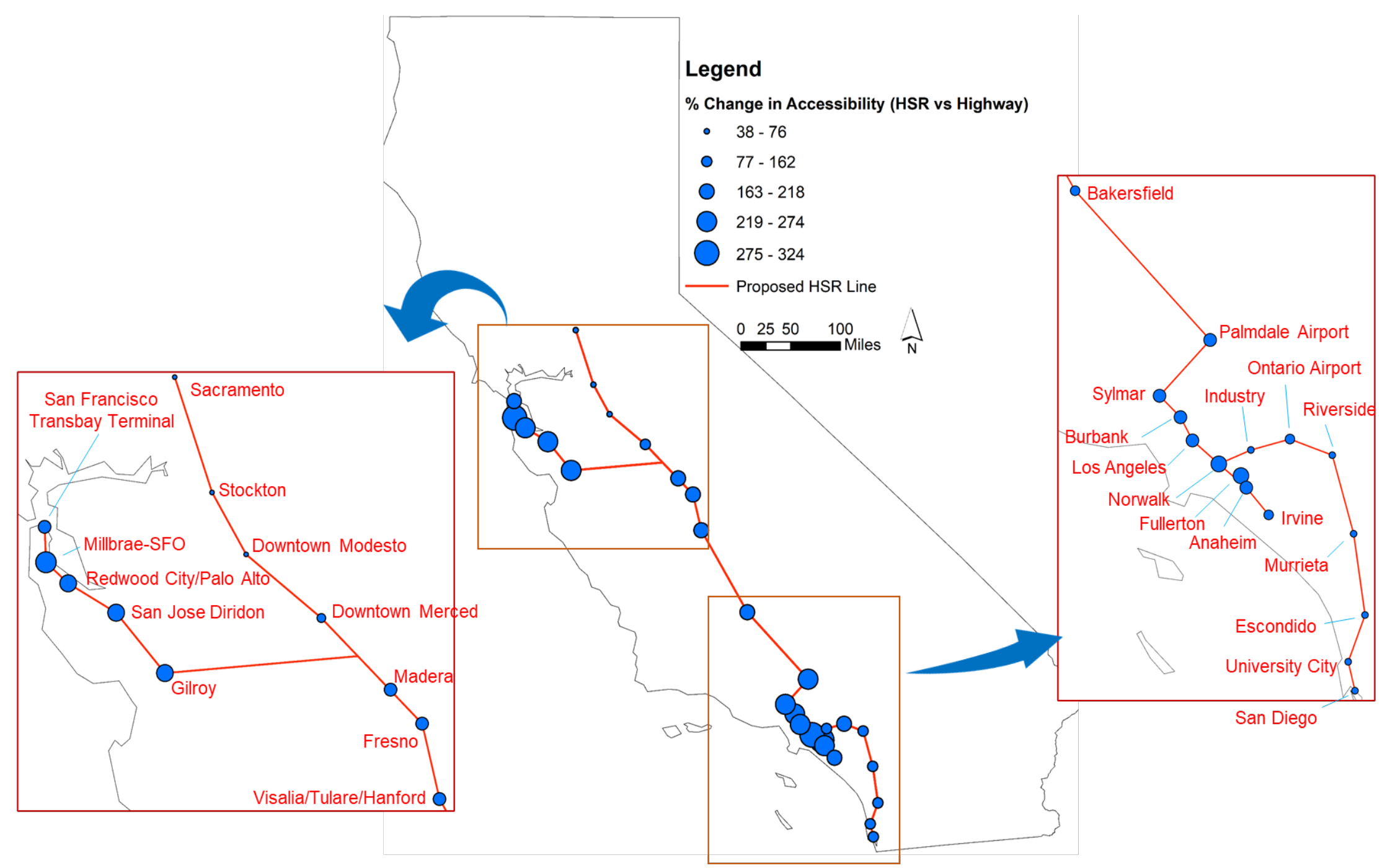


Figure 5. Pareto-Optimal Solution Representation for a Bi-Objective Optimization Problem

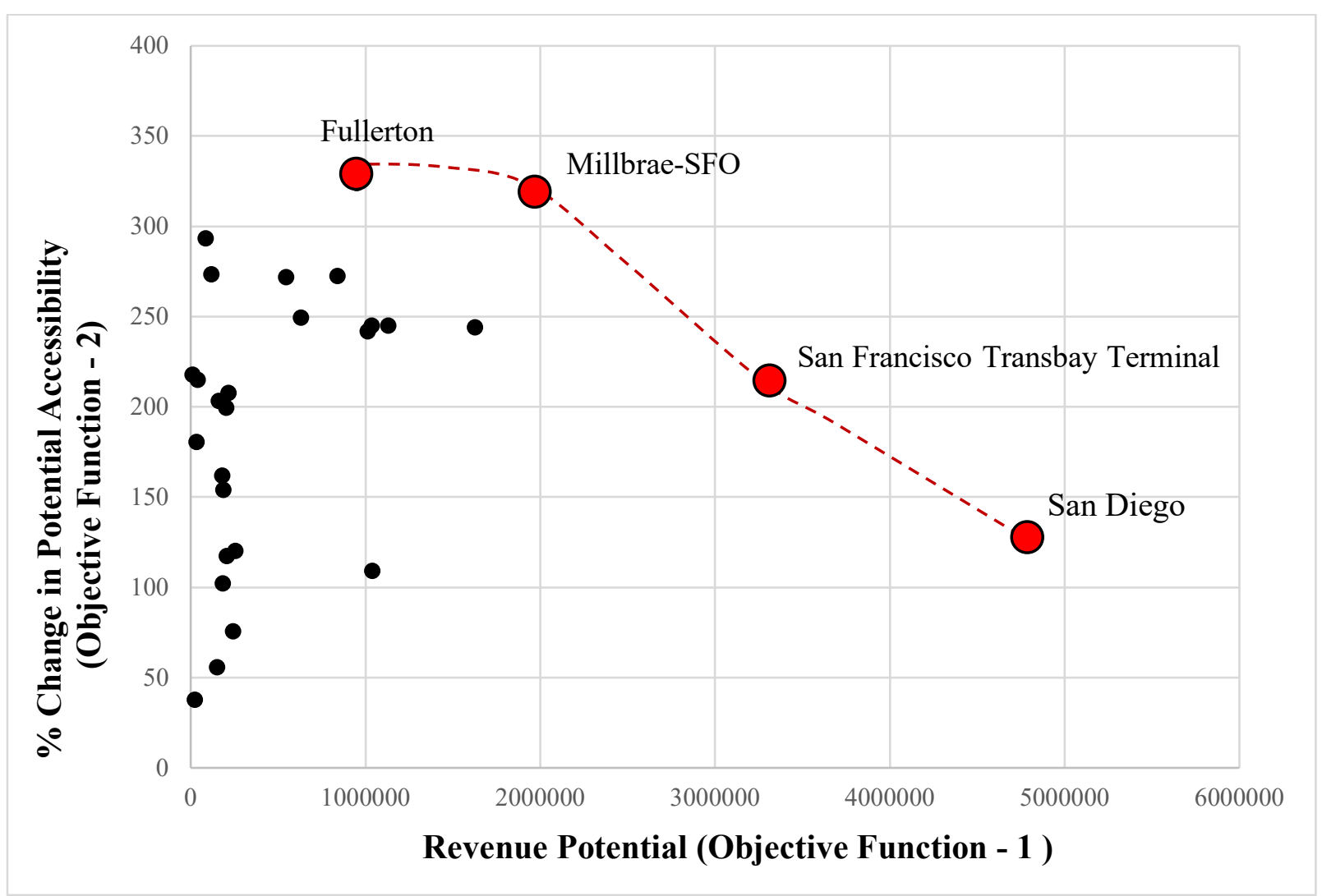

- Dominated Solution $\bigcirc$ Non-dominated Solution 


\section{Summary and Conclusions}

The HSR serves as a fast surface transportation mode facilitating mobility between two spatially separated regions with stations. HSR stations serve as points of connectivity and are selected to be hotspots of economic activities. With the purpose being to spur economic growth with HSR, authorities upgrade and improve existing station infrastructure. Economic growth includes an increase in real estate value and businesses surrounding the stations. However, developing, upgrading, or improving an HSR station requires funds that are often limited. Therefore, various funding options should be explored to promote the development and upgrade of HSR stations to standards that can attract businesses in the surrounding area.

In this research, a methodology is presented that can be deployed to identify stations that could have the potential to attract economic activities after upgrades. It involves using a bi-objective optimization framework for identifying one or more HSR stations from a list of candidates for development. The objective functions maximize the revenue generated from tax collected from the station's surrounding real estate properties and the station's potential accessibility. Subsequently, the solution is presented by constructing a Pareto-optimal front with key proposed stations that decision-makers can focus on for development and upgrade.

Using California's 28 HSR stations as an example, the Pareto-optimal front showed that the four proposed HSR stations of Fullerton, Millbrae-SFO, San Francisco Transbay Terminal, and San Diego would be the best suited for development to increase economic vitality in their surroundings. These four stations stand out as the non-dominated solution of the constructed Pareto-optimal front. The finding could serve as valuable information for California HSR authorities to develop these four key stations to generate an alternate funding source for the HSR project facing funding challenges.

Thus, this research provides useful guidance that HSR authorities and stakeholders can use to identify stations with high economic growth and accessibility potential for a region. Alternatively, the knowledge developed from this research might also help stimulate real estate value increase and business growth surrounding a station by improving its accessibility to other stations on the HSR line. 


\section{Bibliography}

Aldrete, R. M., C. J. Kruse, D. Salgado, S. R. Vadali, A. Mudgal, J. C. Villa, ..., and D. S. Bae. "Leveraging the Value of Land and Landside Access to Fund Port Infrastructure in Texas." Transportation Research Record 2672, no. 11 (2018): 41-52.

Andersson, D. E., O. F. Shyr, and J. Fu. "Does High-Speed Rail Accessibility Influence Residential Property Prices? Hedonic Estimates from Southern Taiwan.” Journal of Transport Geography 18, no. 1 (2010): 166-174.

Bae, C. H. C., M. J. Jun, and H. Park. "The Impact of Seoul's Subway Line 5 on Residential Property Values." Transport Policy 10, no. 2 (2003): 85-94.

Belzer, D., S. Srivastava, M. Austin, T. Bump, and J. Wood. "Transit and Regional Economic Development" (No. FTA CA-26-1007-03). 2011.

Brandt, S., and W. Maennig. "The Impact of Rail Access on Condominium Prices in Hamburg." Transportation 39, no. 5 (2012): 997-1017.

Brisset, S., and F. Gillon. "Approaches for Multi-Objective Optimization in the Ecodesign of Electric Systems." In Eco-Friendly Innovation in Electricity Transmission and Distribution Networks (pp. 83-97). Woodhead Publishing: 2015.

California High-Speed Rail Authority (2020a). https://hsr.ca.gov/high_speed_rail/ (accessed September 22, 2020).

California High-Speed Rail Authority (2020b). https://hsr.ca.gov/high_speed_rail/\#: :text=The\%20system\%20will\%20run\%20from,with \%20up\%20to\%2024\%20stations (accessed October 28, 2020).

California High-Speed Rail Authority (2020c). Capital Costs \& Funding. https://hsr.ca.gov/about/capital_costs_funding/ (accessed November 1, 2020).

California High-Speed Rail Authority (2020d). Millbrae-SFO. https://hsr.ca.gov/high_speed_rail/station_communities/millbrae_sfo.aspx (accessed November 22, 2020).

California High-Speed Rail Authority (2020e). San Francisco. https://hsr.ca.gov/high_speed_rail/station_communities/millbrae_sfo.aspx (accessed November 22, 2020).

California High-Speed Rail Authority (2020f). Los Angeles to Anaheim. https://hsr.ca.gov/high_speed_rail/station_communities/millbrae_sfo.aspx (accessed November 22, 2020).

California High-Speed Rail Authority (2020g). Los Angeles to San Diego. https://hsr.ca.gov/high_speed_rail/station_communities/millbrae_sfo.aspx (accessed November 22, 2020).

Cervero, R., and M. Duncan. "Benefits of Proximity to Rail on Housing Markets: Experiences in Santa Clara County." Journal of Public Transportation 5, no. 1 (2002): 3.

Chandra, S., and R. Mazin. "Quantifying Rail Transit Investments with Appropriate Measures and Metrics.” World Review of Intermodal Transportation Research 9, no. 4 (2020): 313-333. 
Chandra, S., and S. Vadali. "Evaluating Accessibility Impacts of the Proposed America 2050 High-Speed Rail Corridor for the Appalachian Region.” Journal of Transport Geography 37 (2014): 28-46.

Chen, Z., and K. E. Haynes. "Impact of High Speed Rail on Housing Values: An Observation from the Beijing-Shanghai Line.” Journal of Transport Geograpby 43 (2015): 91-100.

Cheng, Y. H. (2010). "High-Speed Rail in Taiwan: New Experience and Issues for Future Development." Transport Policy 17, no. 2 (2010): 51-63.

Cheng, Y. S., B. P. Loo, and R. Vickerman. "High-Speed Rail Networks, Economic Integration and Regional Specialisation in China and Europe." Travel Behaviour and Society 2, no. 1 (2015): 1-14.

Debrezion, G., E. Pels, and P. Rietveld. "The Impact of Rail Transport on Real Estate Prices: An Empirical Analysis of the Dutch Housing Market.” Urban Studies 48, no. 5 (2011): 9971015.

Diao, M. "Does Growth Follow the Rail? The Potential Impact of High-Speed Rail on the Economic Geography of China.” Transportation Research Part A: Policy and Practice 113 (2018): 279-290.

Diaz, R. B., and V. A. Mclean. "Impacts of Rail Transit on Property Values." In American Public Transit Association Rapid Transit Conference Proceedings (pp. 1-8), May 1999.

Edwards, N. "High Speed Rail: Benefits that Add Up: A Report for the Australian Greens." 2012. European Commission (2020a). "Madrid extends high-speed rail link along eastern coast." https://ec.europa.eu/regional_policy/en/projects/major/spain/madrid-extends-highspeed-rail-link-along-eastern-coast (accessed November 3, 2020).

European Commission (2020b). "The new Guillemins district in Liège, Belgium." https://ec.europa.eu/regional_policy/en/projects/bestpractices/Belgique\%20-\%20Belgi\%C3\%83\%C2\%AB/1774 (accessed November 3, 2020).

Federal Railroad Administration (FRA). "Statement of Federal Railroad Administration on Termination of FY '10 Grant Agreement with California High-Speed Rail Authority.” 2019. https://cms7.fra.dot.gov/newsroom/statement-federal-railroad-administrationtermination-fy-\%E2\%80\%9810-grant-agreement-california (accessed November 22, 2020).

Geffen, C. "The Potential for High-Speed Rail in the US." In Sustainable Innovation and Impact (pp. 220-230). Routledge: 2018.

Government Technology (govtech.com). "California High-Speed Rail Faces Mounting Financial Woes.” https://www.govtech.com/fs/transportation/California-High-Speed-Rail-FacesMounting-Financial-Woes.html (accessed November 22, 2020).

Gutiérrez, J. "Location, Economic Potential and Daily Accessibility: An Analysis of the Accessibility Impact of the High-Speed Line Madrid-Barcelona-French Border.” Journal of Transport Geography 9, no. 4 (2001): 229-242.

Hansen, W. G. "How Accessibility Shapes Land Use." Journal of the American Institute of Planners 25, no. 2 (1959): 73-76. 
Hensher, D., Z. Li, and C. Mulley. "The Impact of High Speed Rail on Land and Property Values: A Review of Market Monitoring Evidence from Eight Countries." Road E Transport Research: A Journal of Australian and New Zealand Research and Practice 21, no. 4 (2012): 3.

Hiramatsu, T. "Job and Population Location Choices and Economic Scale as Effects of High Speed Rail: Simulation Analysis of Shinkansen in Kyushu, Japan." Research in Transportation Economics 72 (2018): 15-26.

International Railway Journal. "Austria and Liechtenstein to finance S-Bahn project." https://www.railjournal.com/infrastructure/austria-and-liechtenstein-to-finance-s-bahnproject/ (accessed November 3, 2020).

Kilpatrick, J., R. Throupe, J. Carruthers, and A. Krause. "The Impact of Transit Corridors on Residential Property Values." Journal of Real Estate Research 29, no. 3 (2007): 303-320.

LA County GIS. 2014 California Parcels Dataset. http://egis3.lacounty.gov/dataportal/2015/09/11/california-statewide-parcel-boundaries/ (accessed April 2, 2016).

League of California Cities, Enhanced Infrastructure Financing District. "Tax Increment Tools." https://www.cacities.org/Policy-Advocacy/Hot-Issues/New-Tax-Increment-Tools (accessed December 12, 2020).

Liu, C., S. Erdogan, T. Ma, and F. W. Ducca. "How to Increase Rail Ridership in Maryland: Direct Ridership Models for Policy Guidance." Journal of Urban Planning and Development 142, no. 4 (2016): 04016017.

Long, Y., and W. Zhang. "Prioritizing Future Funding and Construction of the Planned HighSpeed Rail Corridors of China-According to Regional Structure and Urban Land Development Potential Indices." Transport Policy 81 (2019): 381-395.

Longitudinal Employer-Household Dynamics (LEHD). https://onthemap.ces.census.gov/ (accessed August 2, 2020).

Loukaitou-Sideris, A., D. Cuff, T. Higgins, and O. Linovski. "Impact of High Speed Rail Stations on Local Development: A Delphi Survey.” Built Environment 38, no. 1 (2012): 51-70.

Murakami, J., and R. Cervero. "California High-Speed Rail and Economic Development: Station-Area Market Profiles and Public Policy Responses." In Symposium, University of California, Berkeley Faculty Club, December 2010.

Nordic Investment Bank (NIB). "NIB finances new high-speed trains in Sweden." https://www.nib.int/who_we_are/news_and_media/news_press_releases/3581/nib_financ es_new_high-

speed_trains_in_sweden\#: :text=NIB\%20and\%20the\%20Swedish\%20passenger,between \%20Stockholm\%2C\%20Copenhagen\%20and\%20Oslo (accessed November 3, 2020).

Raghuram, G., and Prashanth D. Udayakumar. "Dedicated High Speed Rail Network in India: Issues in Development." IIMA Working Papers WP 2016-03-58, Indian Institute of Management Ahmedabad, Research and Publication Department, 2016. 
Railway Technology. "Is the Turin-Lyon high-speed railway still viable?" https://www.railwaytechnology.com/features/future-of-turin-lyon-high-speed-railway/ (accessed November 8, 2020).

Railway Gazette International. "Brescia high speed line construction begins." https://www.railwaygazette.com/nc/news/single-view/view/brescia-high-speed-lineconstruction-begins.html (accessed November 8, 2020).

Roll, M., and A. Verbeke. "Financing of the Trans-European High-Speed Rail Networks: New Forms of Public-Private Partnerships." European Management Journal 16, no. 6 (1998): 706-713.

Rungskunroch, P., Y. Yang, and S. Kaewunruen. "Does High-Speed Rail Influence Urban Dynamics and Land Pricing?” Sustainability 12, no. 7 (2020): 3012.

Ryan, S. "Property Values and Transportation Facilities: Finding the Transportation-Land Use Connection." Journal of Planning Literature 13, no. 4 (1999): 412-427.

Salon, D., E. Sclar, and R. Barone. "Can Location Value Capture Pay for Transit? Organizational Challenges of Transforming Theory into Practice.” Urban Affairs Review 55, no. 3 (2019): 743-771.

Shi, Y. S., and H. N. Guo. "Temporal-Spatial Impacts of the Shanghai South Railway Station on Housing Prices." Acta Geographica Sinica 64, no. 2 (2009): 167-176.

Tax-rates.org. http://www.tax-rates.org/california/property-tax (accessed November 22, 2020).

TPF. “High Speed Rail Line Madrid - Lisbon / Porto." https://tpf.eu/projects/high-speed-railline-madrid-lisbon-porto/ (accessed November 2, 2020).

Zhang, M., and B. T. Yen. "The Impact of Bus Rapid Transit (BRT) on Land and Property Values: A Meta-Analysis." Land Use Policy 96 (2020): 104684. 


\section{About the Authors}

\section{Shailesh Chandra, PhD}

Dr. Chandra is an associate professor in the Department of Civil Engineering and Construction Engineering Management at California State University, Long Beach (CSULB). He obtained his MS and PhD in civil engineering from Texas A\&M University in 2009 and 2012, respectively. Dr. Chandra has more than twelve years of experience in transportation research focused on transport connectivity, transportation economics, accessibility, urban freight, and sustainability. He has been a principal investigator (PI) for several projects funded by various transportation agencies including the California Department of Transportation (Caltrans) and the United States Department of Transportation (USDOT).

\section{Timothy Thai}

Mr. Thai is an undergraduate student in the Department of Civil Engineering and Construction Engineering Management at CSULB. His research interests include railroad crossings and real estate analysis.

\section{Vivek Mishra}

Mr. Mishra is a graduate student in the Department of Computer Science and Computer Engineering at CSULB. His research interests relate to computer programming and transportation analysis.

\section{Princeton Wong}

Mr. Wong is an undergraduate student in the Department of Computer Science and Computer Engineering at CSULB. His research interests relate to blockchain technology, computer programming, and transportation. 
Founder, Honorable

Norman Mineta*

Secretary (ret.),

US Department of Transportation

\section{Chair,}

Abbas Mohaddes

President \& $\mathrm{COO}$

Econolite Group Inc.

\section{Vice Chair,}

Will Kempton

Retired Transportation Executive

\section{Executive Director,} Karen Philbrick, PhD*

Mineta Transportation Institute

San José State University

\section{Winsome Bowen}

Chief Regional Transportation

Strategy

Facebook

\section{David Castagnetti}

Co-Founder

Mehlman Castagnetti

Rosen \& Thomas

\section{Maria Cino}

Vice President

America \& U.S. Government

Relations Hewlett-Packard Enterprise

\author{
Grace Crunican** \\ Owner \\ Crunican LLC
}

\section{Donna DeMartino}

Managing Director

Los Angeles-San Diego-San Luis

Obispo Rail Corridor Agency

\section{John Flaherty}

Senior Fellow

Silicon Valley American

Leadership Form

\section{William Flynn *}

President \& CEO

Amtrak

\section{Rose Guilbault}

Board Member

Peninsula Corridor

Joint Powers Board

\section{Ian Jefferies*}

President \& CEO

Association of American Railroads

Diane Woodend Jones

Principal \& Chair of Board

Lea + Elliott, Inc.
David S. Kim*

Secretary

California State Transportation

Agency (CALSTA)

Therese McMillan

Executive Director

Metropolitan Transportation

Commission (MTC)

Jeff Morales

Managing Principal

InfraStrategies, LLC

Dan Moshavi, PhD*

Dean, Lucas College and

Graduate School of Business

San José State University

Toks Omishakin*

Director

California Department of

Transportation (Caltrans)

\section{Takayoshi Oshima}

Chairman \& CEO

Allied Telesis, Inc.

Paul Skoutelas*

President \& CEO

American Public Transportation

Association (APTA)
Beverley Swaim-Staley

President

Union Station Redevelopment

Corporation

Jim Tymon*

Executive Director

American Association of

State Highway and Transportation

Officials (AASHTO)

$*$ = Ex-Officio

** $=$ Past Chair, Board of Trustees

\section{Directors}

\section{Karen Philbrick, PhD}

Executive Director

\section{Hilary Nixon, PhD}

Deputy Executive Director

\section{Asha Weinstein Agrawal, PhD}

\section{Education Director}

National Transportation Finance

Center Director

\section{Brian Michael Jenkins}

National Transportation Security

Center Director

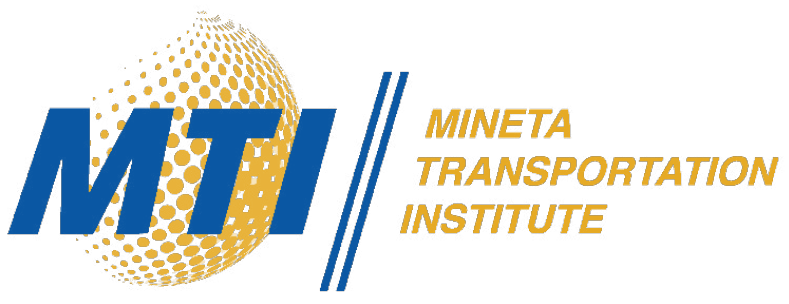

